\title{
Prognostic and diagnostic relevance of hypermethylated in cancer 1 (HIC1) CpG island methylation in renal cell carcinoma
}

\author{
H. EGGERS ${ }^{1 *}$, S. STEFFENS $^{1 *}$, A. GROSSHENNIG ${ }^{2}$, J.U. BECKER ${ }^{4}$, J. HENNENLOTTER ${ }^{3}$ \\ A. STENZL ${ }^{3}$, A.S. MERSEBURGER ${ }^{1}$, M.A. KUCZYK ${ }^{1}$ and J. SERTH ${ }^{1}$ \\ ${ }^{1}$ Department of Urology, Hannover Medical School; ${ }^{2}$ Institute of Biometry, \\ Hannover Medical School, Hannover; ${ }^{3}$ Department of Urology, Eberhard Karls University, \\ Tuebingen; ${ }^{4}$ Department of Pathology, Hannover Medical School, Hannover, Germany
}

Received October 26, 2011; Accepted December 9, 2011

DOI: $10.3892 /$ ijo.2012.1367

\begin{abstract}
The tumour suppressor gene hypermethylated in cancer 1 (HICl) is a transcriptional repressor, which functionally cooperates with $p 53$. Loss of HICl function is associated with the development of various tumor entities. The aim of this study was to elucidate the relevance of $\mathrm{CpG}$ island (CGI) methylation of $\mathrm{HICl}$ in renal cell carcinoma (RCC). DNA methylation of $\mathrm{HICl}$ was analysed in a total of 98 tumor and 70 tumor adjacent normal specimens. After conducting bisulfite conversion, relative methylation levels were quantitated using pyrosequencing. Relative methylation values were compared for paired tumor and normal specimen and for correlation with clinico-pathologic and follow-up data of patients. Tumor-specific hypermethylation could not be detected for the subregion of the HICl - CGI analyzed in this study. Comparing the level of methylation in tumors to clinicopathological data solely, patients without lymph node metastases demonstrated a higher level of methylation compared to patients with lymph node metastases $(\mathrm{p}=0.030)$. Patients recurrence-free survival $(p=0.0074)$ both in univariate as well as bivariate Cox regression analysis. This study identifies $H I C l$ hypermethylation in tumors as an independent predictor of reduced recurrence-free survival, which fits into our current understanding of hypermethylated HICl being a marker for poor prognosis. Therefore, HICl - CGI methylation could be a candidate marker to improve individualized therapy and risk stratification.
\end{abstract}

\section{Introduction}

The incidence of RCC in the US and Europe has increased significantly in the past decades and although RCC only

Correspondence to: Professor Markus A. Kuczyk, Department of Urology, Hannover Medical School (OE 6240), Carl-Neuberg-Str. 1, 30625 Hannover, Germany

E-mail: kuczyk.markus@mh-hannover.de

*Contributed equally

Key words: renal cell carcinoma, Hypermethylated in Cancer 1, methylation, Pyrosequencing, $\mathrm{CpG}$ island, recurrence-free survival accounts for $\sim 2-3 \%$ of all human malignancies, it is the sixth leading cause of cancer related death (1-3). RCC is defined as adenocarcinoma of the renal tubular epithelium and summarizes a heterogeneous group with distinct histologic, genetic and molecular features also used for prediction of clinical outcome and as diagnostic tools (4). Since most of the known gene alterations are found in a minority of cases, sporadic RCC is thought to arise from multiple genetic and epigenetic events $(5,6)$. So far only the PBRMI and $V H L$ genes show frequent mutation in $>30 \%$ of RCC (7). Thus, beside PBRM1, showing mutation in $41 \%$ of primary clear-cell RCC, analysis of about 3500 other genes demonstrated no other mutation (8).

In contrast, Morris et al, were able to show that epigenetic alterations are present in at least a dozen of genes for RCC $(9,10)$. For other genes like SFRPI and RASSFI an association of $\mathrm{CpG}$ island (CGI) methylation with gene-silencing in RCC has already been shown and their possible role as prognostic and/or diagnostic tools was reported (11-16). Though many epigenetic alterations were found to exist in RCC only few of them have been subject of research exploring their functional and clinical relevance.

One of these potential marker genes is hypermethylated in cancer 1 (HIC1), for which CGI-DNA methylation in various human malignancies has been detected such as carcinoma of the prostate, lung, germ cell, breast and lymphoma (17).

$\mathrm{HICl}$ is a tumor suppressor gene located on chromosome 17p13.3. HICl consists of a DNA-binding C-terminal domain (five Krüppel-like $\mathrm{C} 2 \mathrm{H} 2$ zinc fingers), a $\mathrm{N}$-terminal domain (BTB/POZ complex) for protein-protein interactions and a central region while the last two have been described as autonomous transcriptional repression domains $(18,19)$. HICl was shown to interact with silent mating type information regulation 2 homolog1 (SIRT1) leading to an inactivation of p53 when silenced as part of response to stress (20). In addition, very recently an interaction with the SWI/SNF chromatin-remodeling complexes associated with the transcriptional regulation of multiple cell cycle control-related genes was discovered $(21,22)$. The pubished data strongly indicates the crucial role of HICl as a mediator of cancer development and therefore as a possible tool to predict tumor prognosis. To our knowledge there has been up to now only one study investigating the role of HICl in RCC. In 1993, Makos et al concluded that HICl hyper- 
methylation precedes the manifestation of genetic alterations in 17p and is involved in development of RCC. For methylation analysis NotI and NotI/BamHI restriction analysis were used and compared with the frequency of p53 mutation and $17 \mathrm{p}$ allelic loss. In comparison early and late stage tumors show higher frequencies of methylation than of $17 \mathrm{p}$ allelic loss and even less p53 mutation (23).

However, the small number of 31 tumor samples and the lack of clinic-pathologic data as well as specific quantitative methylation create the need for this study to further investigate the possible prognostic and/or diagnostic value of region-specific HICl CpG island (CGI) methylation in a collective of $98 \mathrm{RCC}$ and corresponding normal kidney tissue samples.

\section{Materials and methods}

Controls and cell lines. 'EpiTect Control DNA, methylated' (QM) and 'EpiTect Control DNA, unmethylated' (QU) were used as commercially purchased positive and negative controls, which consist of completely methylated i.e. unmethylated and bisulfitconverted human DNA (Qiagen, Hilden, Germany). Primary renal proximal tubular epithelial cells (RPTEC) and human prostate epithelial cells (PrEC) were purchased from Lonza (Basel, Switzerland) and malignant cell lines of kidney (ACHN, 786-O, RCC-GS, RCC-HS, RCC-MF), prostate (LNCap, DU-145, PC-3) and bladder (RT-112, CLS-439, HB-CLS-1, HB-CLS-2, EJ-28, 5637, T24) were obtained through cell line services (CLS, Heidelberg, Germany). Histopathological classification status of primary cancer were: pT1, N0, Mx, G1 for RCC-HS; pT2, N1, Mx, G2-3 for RCC-MF and pT3b, N0, M1, G3 for RCC-GS cell lines. Cells were grown according to the recommendations of the supplier, snap-frozen in liquid nitrogen and stored at $-80^{\circ} \mathrm{C}$ until extraction of nucleic acids.

Tissue specimens. Ninety-eight renal cell carcinomas of patients subjected to kidney surgery between 2001 and 2005 at the Eberhard Karls University Tuebingen, were collected. The study group consisted of 72 clear-cell RCC, 20 papillary RCC and 6 of mixed histologies. Matched paired tissue samples of tumor and corresponding tumor-free tissue were obtained from 58 RCCs. Corresponding tumor-free tissues were isolated $\sim 2-0.5 \mathrm{~cm}$ adjacent from the primary tumor. All tumors were freshly obtained from the urological department's operating room. Resected tissues were snap-frozen and stored at $-80^{\circ} \mathrm{C}$. The ethics committee of the institution approved the study and informed consent was obtained from the patients. Two pathologists re-evaluated all specimens with respect to tumor stage, grade, and histological subtypes. Tumor stages were assessed according to the UICC 2002 issue of the TNM system and nuclear grading was based on the Fuhrman grading system. Histological subtypes were assessed according to the consensus classification of renal cell neoplasia. Organ-confined RCC was defined as $\mathrm{pT} \leq 2, \mathrm{NO} /$ M0 whereas advanced tumors were defined as $\mathrm{pT} \geq 3$ and/or $\mathrm{N}^{+}$ $\mathrm{M}^{+}$. Data were collected by physicians and data managers and subsequently maintained by a relational database. Clinical and histopathological data are summarized in Table I.

Follow-up assessment. For assessment of follow-up data urologists and general practitioners of the patients were contacted. Every new appearance of disease was defined as recurrence. The
Table I. Clinical and histopathological data of patients with renal cell cancer.

\begin{tabular}{lrr}
\hline HIC1 & All RCC & ccR \\
\hline Cases & & \\
N & 98 & \\
TNM-classification & & \\
T1 & 55 & 38 \\
T2 & 6 & 4 \\
T3 & 36 & 30 \\
T4 & 1 & 0 \\
Tx & 0 & 0 \\
N0 & 86 & 65 \\
N1 & 12 & 7 \\
M0 & 76 & 53 \\
M1 & 22 & 19
\end{tabular}

Paired tissue samples ${ }^{c}$ $\mathrm{N}$

Grading

G1

G2

G3

Gender

Male

64

44

Female

Status

Localized tumor $^{\mathrm{d}} \quad 52$

Advanced tumor $^{\mathrm{d}} \quad 46 \quad 38$

Age

Min 35

35

Mean

62.8

61.7

Max

91

90

Progression/follow-up data

$\begin{array}{llc}\mathrm{N} & 57 & 42 \\ \text { Mean age (years) } & 64.7 & 65.0 \\ \text { Male } & 36 & - \\ \text { Female } & 21 & -\end{array}$

ancluding mixed and unclassified RCC. 'Including clear-cell, papillary, mixed and unclassified renal cell carcinoma. 'Tumor (TU) and adjacent benign renal tissue (adjacent normal tissue; adN). ${ }^{\mathrm{d}}$ Localized is defined as pT $\leq 2, \mathrm{~N} 0, \mathrm{M} 0$ and G1-2; advanced tumors as $\mathrm{pT} \geq 3$ and/ or $\mathrm{N}^{+} / \mathrm{M}^{+}$and $\mathrm{G} 2-3$ and/or $\mathrm{N}^{+} / \mathrm{M}^{+}$and G2-3. ccRCC, clear-cell renal cell carcinoma, subset of all RCC.

duration of follow-up was calculated from the date of surgery to the date of either recurrence as defined before or the date of last follow-up in case of recurrence-free survival within the observation period. Follow-up assessment ended in April 2010.

DNA extraction and bisulfite conversion. Total DNA extraction of 20 serial frozen sections $(20 \mu \mathrm{m})$ from each tumor and 


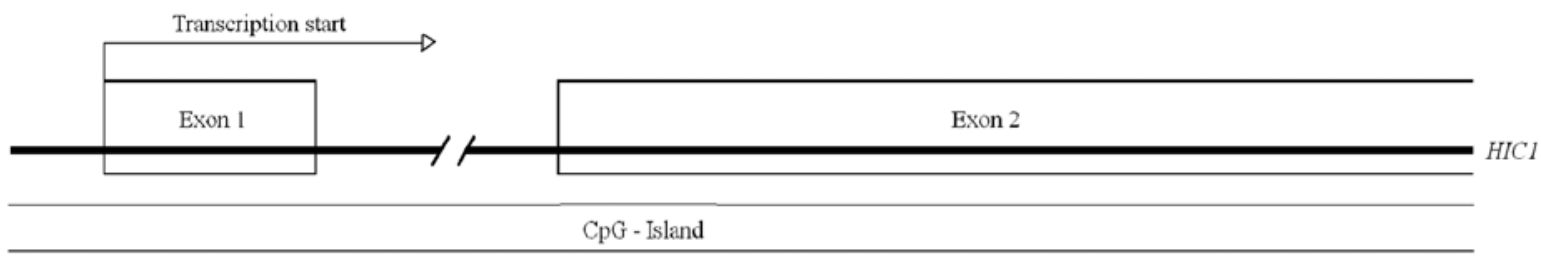

Pyro-Sequence

Figure 1. Schematic figure of the HICl transcript used for pyrosequencing in relation to CpG-Island and HICl-Gen.

Table II. Overview of methylation analysis in statistical comparison with clinicopathological parameters.

\begin{tabular}{|c|c|c|c|c|c|c|}
\hline \multirow[b]{2}{*}{$\mathrm{HICl}$ methylation } & \multicolumn{2}{|c|}{ Rel. methylation (mean) } & \multirow[t]{2}{*}{ p-value } & \multirow{2}{*}{$\begin{array}{l}\text { Odds } \\
\text { ratio } \\
(\mathrm{OR})\end{array}$} & \multirow{2}{*}{$\begin{array}{l}95 \% \text { Confidence } \\
\text { interval } \\
\text { (CI) }\end{array}$} & \multirow{2}{*}{$\begin{array}{c}\text { Statistical } \\
\text { method }\end{array}$} \\
\hline & $(\%)$ & $(\%)$ & & & & \\
\hline \multicolumn{7}{|l|}{ All RCC } \\
\hline Paired tissue samples adN/TU & 17.5 & 19.7 & 0.35 & - & - & Paired t-test \\
\hline $\mathrm{ppRCC} / \mathrm{ccRCC}$ & 22.3 & 17.6 & 0.23 & 0.98 & $0.95-1.01$ & Log regression \\
\hline Localized/advanced ${ }^{\mathrm{b}}$ & 18.0 & 18.4 & 0.89 & 1.02 & $0.98-1.03$ & Log regression \\
\hline Grading low/high grade ${ }^{c}$ & 17.4 & 22.5 & 0.24 & 1.02 & $0.99-1.06$ & Log regression \\
\hline Metastases M0/M1 & 17.5 & 20.7 & 0.39 & 1.01 & $0.98-1.04$ & Log regression \\
\hline Lymph node metastases N0/N1 & 19.6 & 7.9 & 0.03 & 0.91 & $0.82-0.98$ & Log regression \\
\hline \multicolumn{7}{|l|}{ Clear cell RCC } \\
\hline Paired tissue samples adN/TU & 15.8 & 19.5 & 0.18 & - & - & Paired t-test \\
\hline Localized/advanced ${ }^{\mathrm{b}}$ & 15.1 & 19.8 & 0.20 & 1.02 & $0.99-1.06$ & Log regression \\
\hline Grading low/high grade ${ }^{c}$ & 16.2 & 24.5 & 0.09 & 1.03 & $0.99-1.08$ & Log regression \\
\hline Metastases M0/M1 & 16.2 & 21.5 & 0.20 & 1.02 & $0.99-1.06$ & Log regression \\
\hline Lymph node metastases N0/N1 & 18.9 & 5.5 & 0.082 & 0.85 & $0.66-0.97$ & Log regression \\
\hline
\end{tabular}

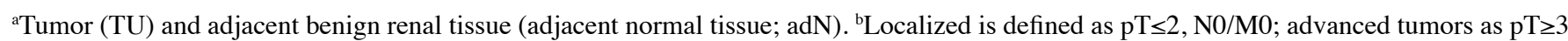
and/or $\mathrm{N}^{+} / \mathrm{M}^{+}$. ${ }^{c}$ Low grade tumor (G1-2); high grade tumor (G2-3). Bold text, statistically significant.

normal specimen was performed using proteinase $\mathrm{K}$ digestion and DNA extraction via standard phenol/chloroform extraction. Each $1 \mu \mathrm{g}$ of extracted DNA was then subjected to bisulfite conversion as described previously and aliquots were stored at $-80^{\circ} \mathrm{C}$ (24). Additionally, two serial cuttings of each tissue sample were stained with hematoxylin-eosin and re-evaluated by pathologists.

Bisulfite-pyrosequencing for HIC1 CGI methylation analysis. Methylation analysis of $\mathrm{HICl} \mathrm{CpG} \mathrm{sites} \mathrm{within} \mathrm{the} \mathrm{CGI} \mathrm{(Fig.} \mathrm{1)}$ was conducted using bisulfite-pyrosequencing according to the manufactures protocol (Qiagen, Hilden, Germany). Quantitative methylation analysis of ten CpG-sites was carried out following semi-nested PCR.

For first round amplification $50 \mathrm{ng}$ of converted DNA, $0.4 \mu \mathrm{M}$ of each primer F1 (5'-TTG GAT TAT GAT ATG GTG AG-3') and Runiv (5'-GGG ACA CCG CTG ATC GTT TAC TTA AAA CA-3'), 1 unit Taq polymerase (Qiagen), $0.2 \mathrm{mM}$ dNTPs, $2 \mathrm{mM} \mathrm{MgCl}_{2}$ and $1.1 \mu \mathrm{l}$ of the included reaction buffer were mixed and filled up to a final volume of $10 \mu \mathrm{l}$ with $\mathrm{H}_{2} \mathrm{O}$. PCR was carried out with the following settings: initial denaturation at $95^{\circ} \mathrm{C}$ for $180 \mathrm{sec} ; 45$ cycles with $45 \mathrm{sec}$ of denaturation at $95^{\circ} \mathrm{C}$, annealing at $56^{\circ} \mathrm{C}$ for $45 \mathrm{sec}$, primer extension at $73^{\circ} \mathrm{C}$ for $45 \mathrm{sec}$ and $180 \mathrm{sec}$ for the last cycle. The second round of amplification was performed at an annealing temperature of $58^{\circ} \mathrm{C}$ using $1 \mu \mathrm{l}$ of the first PCR product and primers F2 (5'-GTT TGG TGT TGG ATT TTA T-3') and the biotinylated universal primer RBio (Biotin-5'-GGG ACA CCG CTG ATC GTT TA-3') according to the universal primer concept previously reported (25).

Following single strand isolation pyrosequencing was done using $0.3 \mu \mathrm{M}$ of the sequencing primer (GTGTTGGATT TTATTTATAT). Measurements were performed according to the manufacturers protocol using the PyroMark Q24 pyrosequencing system (Qiagen). Probes passing automatic quality control of the manufactures software were subjected to final evaluation of methylation by calculating the mean $\mathrm{CpG}$-site methylation.

Statistical analyses. All analyses were performed exploratory, e.g. p-values are descriptively. Group comparisons between tumor and normal renal tissues according to HICl methylation levels were performed using the paired t-test. Differences between renal tumor sub-groups (clear cell vs. papillary, local- 

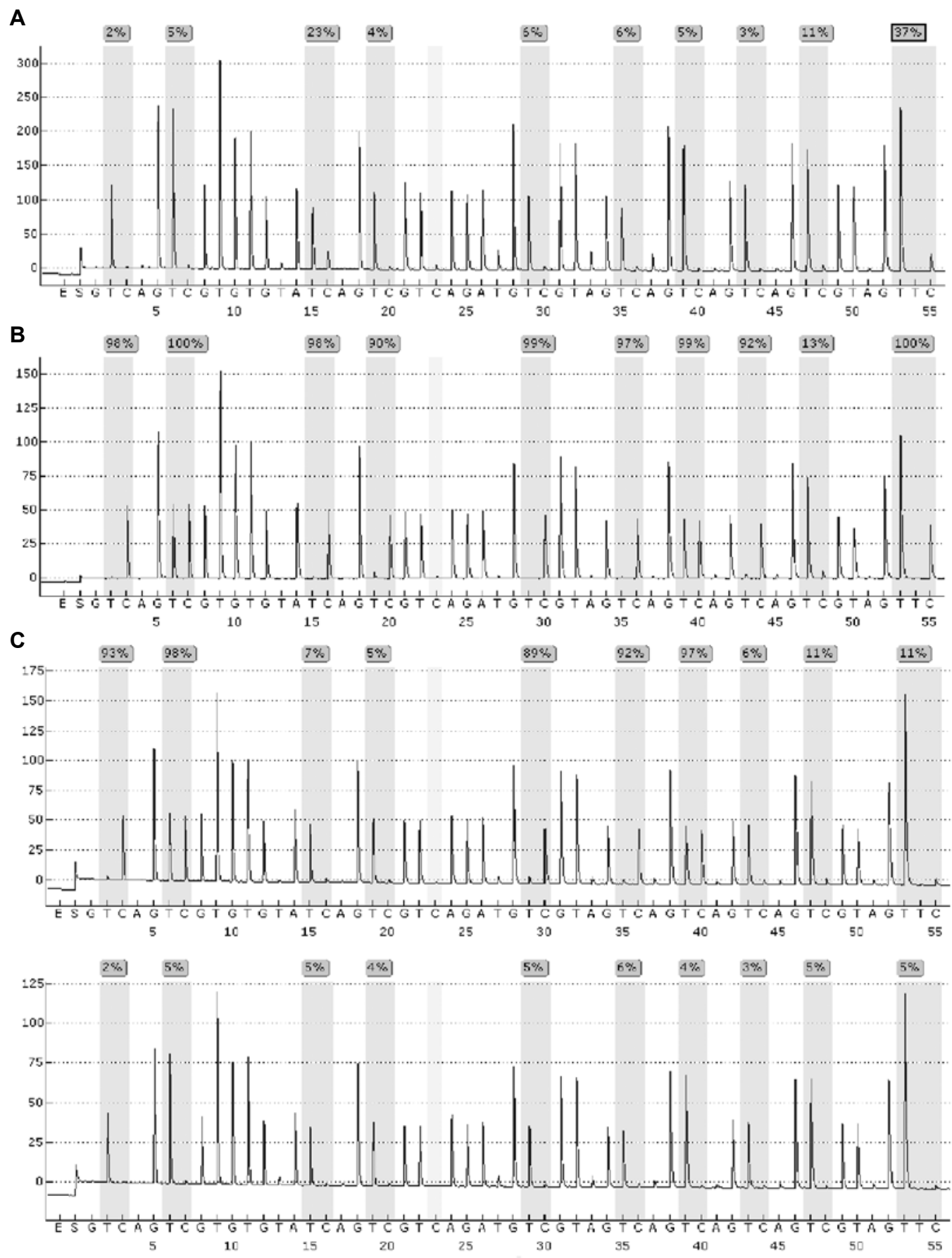

Figure 2. Methylation analysis of ten CpG-sites using pyrosequencing of the HICl transcript. (A) negative QU and (B) positive control QM DNA. Patient samples (C).

ized vs. advanced), lymph node status and distant metastasis were assessed by univariate logistic regression, which was also used to evaluate the association between $\mathrm{HICl}$ methylation levels and tumor stage, grade or tumor diameter following dichotomization of values. For visual comparison of the distribution of methylation values obtained for different groups bean plot analyses were applied as an alternative to boxplots. The individual observations are shown as small lines in a one-dimensional scatter plot, the estimated density of the distributions is visible and the mean is shown. Furthermore, uni- and bivariable Cox regression models examined recurrence-free survival. Descriptive hazard ratios (HR), as well as respective $95 \%$ confidence intervals (95\% CI) and p-values were calculated. In addition, Kaplan-Meier curves were drawn for visualization. All analyses were performed using the R (version 2.12 including libraries 'beanplot', 'lattice' and 'survival') and Java Gui for R 1.7-0. The 'maxRank' package was used to calculate the cutpoint for survival analysis. In all tests, $\mathrm{p}<0.05$ was considered to indicate significance.

\section{Results}

Controls and cell lines. Converted methylated (QM) and unmethylated (QU) control DNAs and DNA from urological cancer cell lines as well as primary normal cells were analyzed using 


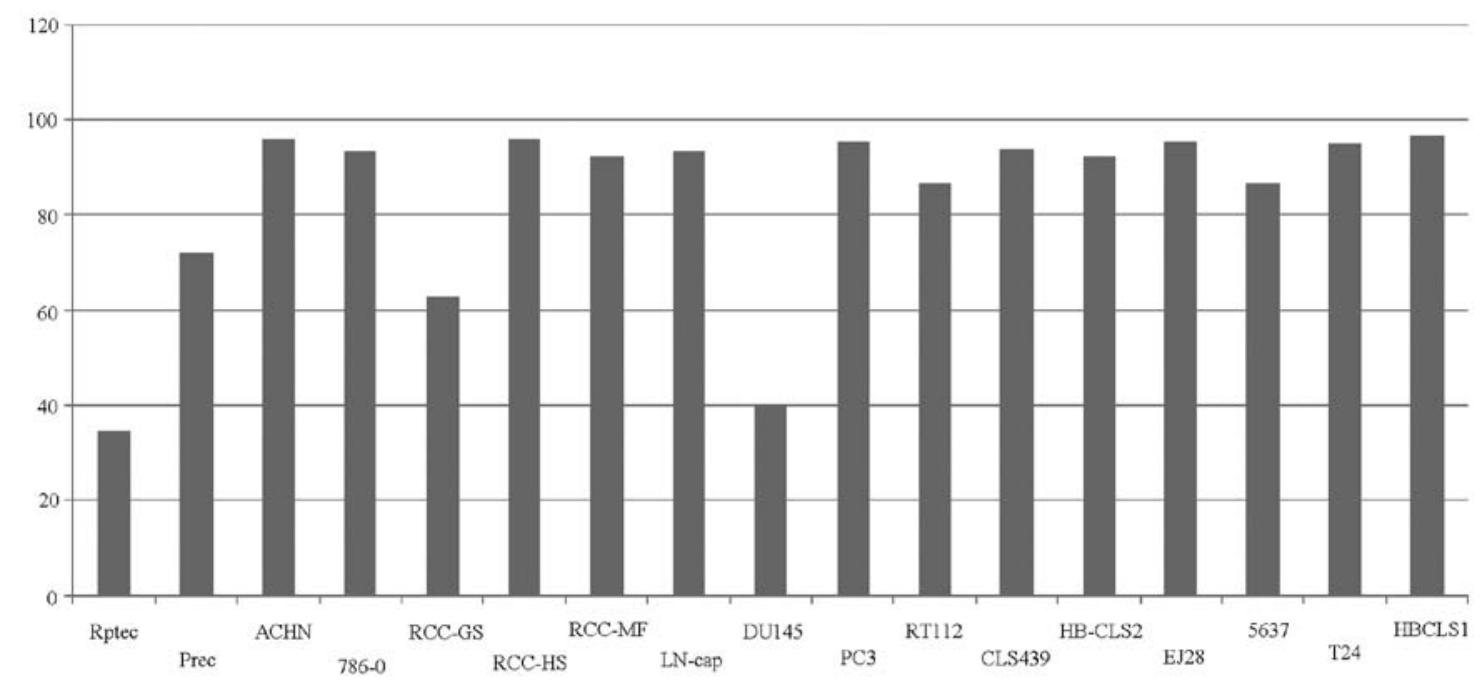

- $\mathrm{HICl} \%$ Methylation

Figure 3. Relative methylation detected by pyrosequencing of 17 cell lines.

A

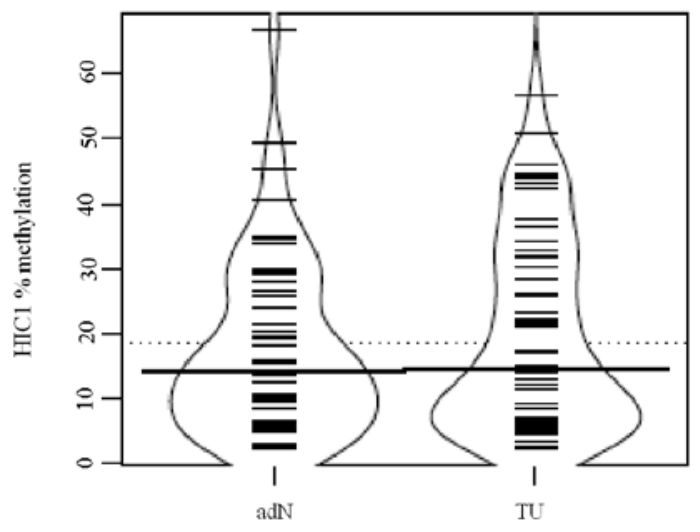

C

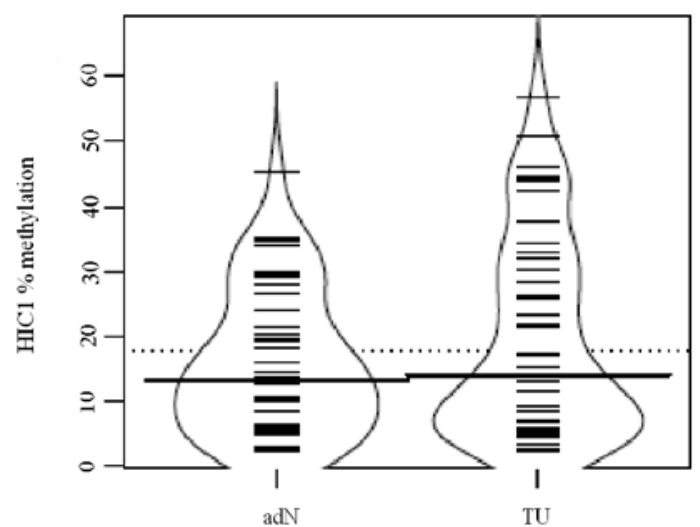

B

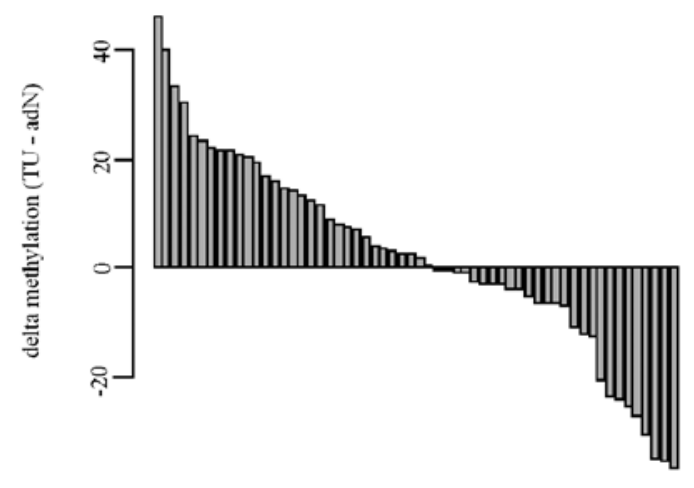

D

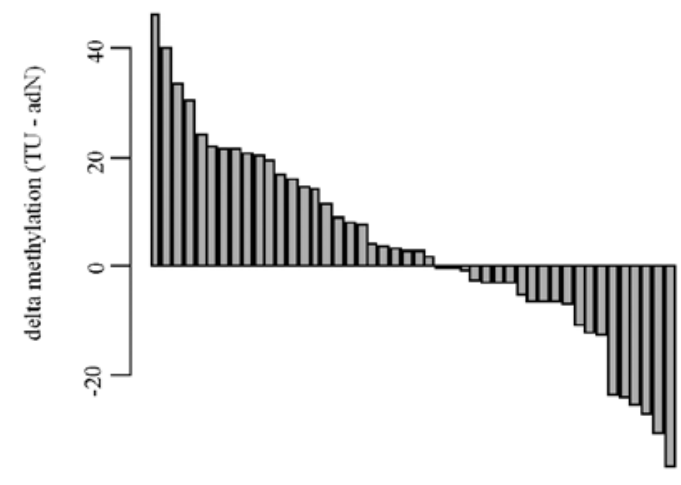

Figure 4. Distribution of relative HICl methylation in paired tumor (TU) and corresponding normal tissue (adN) of (A) all RCC, (B) all RCC paired samples. Sorted methylation difference plots are showed for paired samples (TU - adN) of (C) ccRCC and (D) ccRCC tissues.

pyrosequencing. QM and QU showed mean relative methylation values of $89 \%$ and $10 \%$ respectively. Both DNAs exhibited heterogeneity in methylation including $\mathrm{CpG}$ sites with higher (QU) or lower methylation (QM) (Fig. 2). Malignant kidney cell lines (ACHN, 786-O, RCC-GS, RCC-HS, RCC-MF) show methylation in most cases of above $90 \%$ while non malignant renal or prostatic primary cells were measured between 35 and $72 \%$ methylation (Rptec, Prec) (Fig. 3). 
Table III. Overview of univariate and bivariate methylation analysis for recurrence-free survival.

\begin{tabular}{|c|c|c|c|c|c|c|}
\hline \multirow[b]{2}{*}{ HICl methylation } & \multicolumn{3}{|c|}{ Univariate Cox regression analysis } & \multicolumn{3}{|c|}{ Bivariate Cox regression analysis } \\
\hline & p-value & $\begin{array}{l}\text { Hazard } \\
\text { ratio } \\
(\mathrm{HR})\end{array}$ & $\begin{array}{l}95 \% \text { Confidence } \\
\text { interval } \\
(\mathrm{CI})\end{array}$ & p-value & $\begin{array}{l}\text { Hazard } \\
\text { ratio } \\
(\mathrm{HR})\end{array}$ & $\begin{array}{l}95 \% \text { Confidence } \\
\text { interval } \\
(\mathrm{CI})\end{array}$ \\
\hline \multicolumn{7}{|c|}{ Methylation vs. distant metastases (M0/M1) } \\
\hline Methylation & 0.0074 & 3.9998 & $1.45-11.03$ & 0.0284 & 3.1649 & $1.13-8.88$ \\
\hline Distant metastases (M0/M1) & 0.000049 & 7.7541 & $2.89-20.84$ & 0.0003 & 6.4491 & $2.36-17.59$ \\
\hline \multicolumn{7}{|c|}{ Methylation vs. LN-metastases (N0/N1) } \\
\hline Methylation & & & & 0.0065 & 4.0945 & $1.48-11.30$ \\
\hline LN-metastases & 0.0641 & 3.3052 & $0.93-11.72$ & 0.0520 & 3.5189 & $0.99-12.52$ \\
\hline \multicolumn{7}{|c|}{ Methylation vs. state of disease (loc/adv) ${ }^{\mathrm{a}}$} \\
\hline Methylation & & & & 0.0013 & 5.4381 & $1.94-15.27$ \\
\hline State of disease $(\mathrm{loc} / \mathrm{adv})^{\mathrm{a}}$ & 0.0016 & 7.6299 & $2.17-26.85$ & 0.0004 & 9.7658 & $2.73-34.88$ \\
\hline \multicolumn{7}{|l|}{ Methylation vs. Gender } \\
\hline Methylation & & & & 0.0075 & 3.9943 & $1.45-11.02$ \\
\hline Gender & 0.2192 & 2.0334 & $0.66-6.31$ & 0.2232 & 2.0237 & $0.65-6.29$ \\
\hline \multicolumn{7}{|c|}{ Methylation vs. dichotomized tumor diameter } \\
\hline Methylation & & & & 0.0232 & 4.1774 & $1.22-14.35$ \\
\hline Dichotomized tumor diameter & 0.5046 & 1.4981 & $0.46-4.91$ & 0.4123 & 1.6459 & $0.50-5.42$ \\
\hline \multicolumn{7}{|c|}{ Methylation vs. dichotomized patient's age } \\
\hline Methylation & & & & 0.0074 & 4.0013 & $1.45-11.05$ \\
\hline Dichotomized age & 0.9009 & 1.0643 & $0.40-2.84$ & 0.9885 & 0.9928 & $0.37-2.65$ \\
\hline
\end{tabular}

${ }^{\mathrm{a}} \mathrm{loc}$, localised is defined as $\mathrm{pT} \leq 2, \mathrm{~N} 0, \mathrm{M} 0$ and G1-2; adv, advanced is defined as $\mathrm{pT} \geq 3$ and/or $\mathrm{N}^{+} / \mathrm{M}^{+}$or G2-3. Bold text, statistically significant.

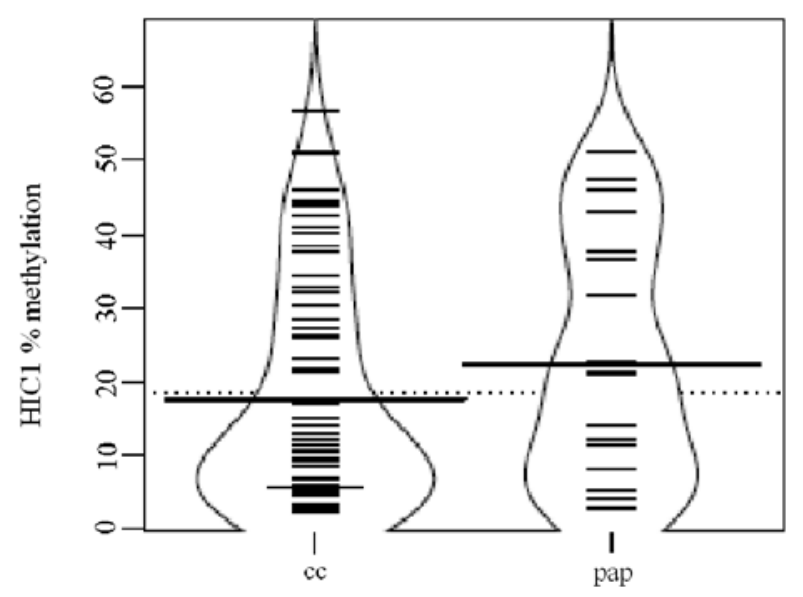

Figure 5. HIC1 methylation levels comparing the histologic entities of clearcell RCC and papillary RCC.

HICl CGI methylation in paired tumor and corresponding normal tissue samples. We found no difference in mean methylation levels of $\mathrm{HICl}$ comparing tumor and corresponding normal renal tissue in paired sample analysis $(\mathrm{p}=0.35$; paired $\mathrm{t}$-test; Fig. 4). A difference was neither found between tumor and corresponding normal tissues in subgroup analysis of ccRCC $(\mathrm{p}=0.18$; paired t-test; Fig. 4$)$.
HICl CGI methylation and association with clinical and histopathologic parameters. We investigated whether statistical association can be detected between CGI methylation of $\mathrm{HICl}$ and clinicopathological parameters (Table II). The median age of the cohort was 62.8 years, 64 patients were men and 34 patients were women.

Comparing the different histologic entities we found no difference in tissue specific mean $\mathrm{HICl}$ methylation between papillary RCC and clear-cell RCC ( $\mathrm{p}=0.23$; univariate logistic regression; Fig. 5).

In contrast, a lower level of methylation was detected to be significantly associated with the presence of lymph node metastasis in RCC as well as a trend was found in subgroup analysis of ccRCC ( $\mathrm{p}=0.030 ; \mathrm{p}=0.082$; univariate logistic regression; Fig. 6). However, no significant statistical association was observed for histological grading, TNM group stage and the presence of distant metastases (Table II).

HICl CGI methylation and association with recurrence-free survival. HICl CGI methylation showed an association with recurrence-free survival (Table III) in univariate analysis using a Cox proportional hazard model and a cutpoint of relative methylation of $21.3 \%$. We found a Hazard Ratio (HR) of 4.0 $(\mathrm{p}=0.0074$; Fig. 7). Using the Cox proportional hazard model for pairwise bivariate analysis of $\mathrm{HICl}$ CGI methylation with the clinicopathologic parameters we detected HRs from 3.1 to 5.4 
A

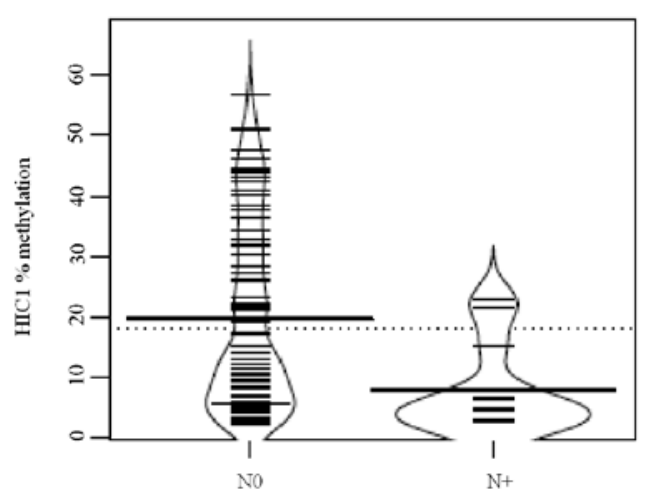

B

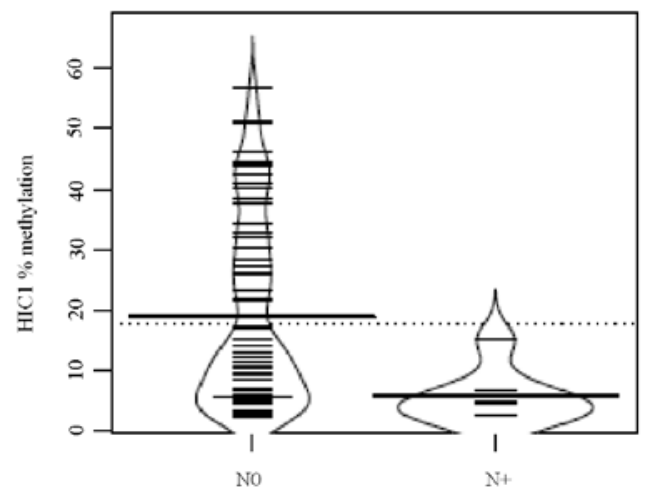

Figure 6. HIC1 methylation in correlated to tumors with $\left(\mathrm{N}^{+}\right)$and without (N0) lymph node metastases in (A) all RCC and (B) ccRCC.

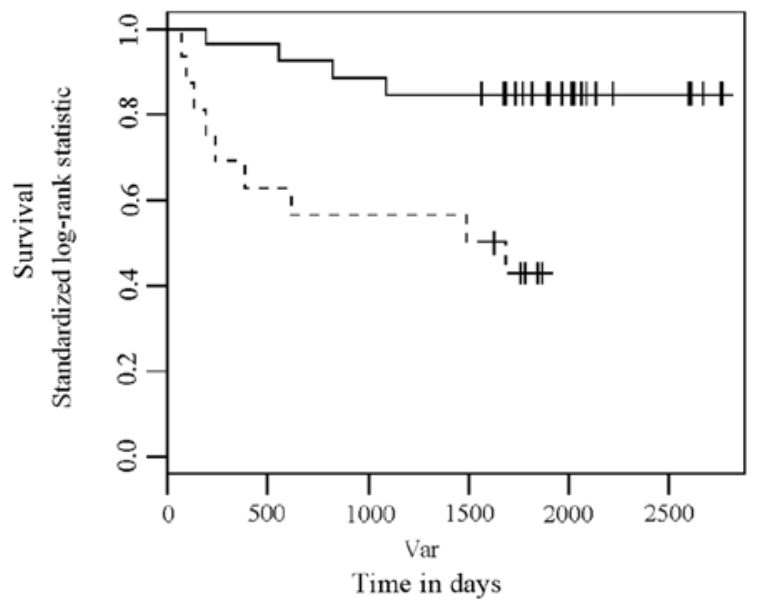

Figure 7. Recurrence-free survival associated to patients with methylation above the calculated cutpoint (dotted line) and to patients with methylation beneath the cutpoint (continuous line).

and p-values between 0.001 and 0.028 for the bivariate regression models (Table III). Only the presence of distant metastases (HR: 3.1649 vs. 6.4491) and state of disease (HR: 5.4381 vs. 9.7658) also exhibited statistically significant HR's methylation levels of the HICl CGI in bivariate comparison.

\section{Discussion}

In 1993, Makos et al described that the hypermethylation of the genomic locus D17S5, later identified to harbor HIC1, precedes the manifestation of chromosome 17p alterations in RCC (23) and is involved in cancer development (18). Makos et al measured from methylation via NotI and NotI/BamHI restriction analysis and compared the frequency of methylation with the occurence of p53 tumor suppressor gene mutation and allelic loss of chromosome $17 \mathrm{p}$. In comparison early and late stage tumors showed higher frequencies of methylation than of $17 \mathrm{p}$ allelic loss and even less p53 mutation (23). The microsatellite marker D17S5 subsequently led to the identification of the HIC1 tumor supressor gene, meanwhile identified to exhibit CGI hypermethylation in many human cancers. To our knowledge this study is the first that carried out a quantitative measurement of $\mathrm{HICl}$
CGI methylation. Our study shows that HICl CGI methylation is associated with recurrence-free survival and therefore, might be a possible prognostic marker for RCC prognosis.

This study quantitatively analysed subregion-specific HICl CGI methylation in RCC and corresponding benign kidney tissues. However, we did not find tumor-specific hypermethylation as could have been expected regarding the data of Makos et al (23) as well as the frequently shown hypermethylation of HICl in several other tumor entities (18). On the one hand, our analysis might be not comparable to the study of Makos et al (23) considering that this study used restriction analysis for detection of methylation and did not provide quantitative data. On the other hand, our study measured only part of the HICl CGI that covers a total of $764 \mathrm{CpG}$ sites according to the annotation given by the UCSC table browser (http://genome.ucsc.edu/) (Fig. 1). Taking into account that to our knowledge, no comprehensive HICl CGI methylation analysis has been reported at yet it is possible that heterogeneity of methylation patterns in this $\mathrm{CpG}$-island is responsible for the divergent findings, a problem that has been adressed recently for the Gremlinl (GREM-1) gene CGI (26). Moreover, a recently published comparison of different methods for methylation detection demonstrated a high concordance between the results obtained by pyrosequencing and bisulfite sequencing, accepted as gold standard of methylation analysis (27).

Epigenetic alterations of $\mathrm{HICl}$ have been described to occur in several tissues. In general, normal tissue seems to ubiquitously express $\mathrm{HICl}$ (17). Therefore, Wales et al assumed that most benign tissues do not demonstrate HICl methylation $(17,18,28)$. At the same time a single methylated allele of $\mathrm{HICl}$ has been found in benign tissues including kidney, breast, prostate, brain and cerebellum giving reason for authors to suggest that these tissues are predisposed to inactivation of $\mathrm{HICl}$ (28-31). Fleuriel et al postulated that these tissues might have a generally higher risk for tumor development $(17,18,28)$. This assumption is supported by the reported hypermethylation of HICl in prostate, breast, gastric, liver, esophageal and human male non-seminomatous germ cell tumors (18). Additionally, hypermethylation and associated loss of HICl-expression have been shown in several tumor cell lines as well as in primary brain and colon cancer (17). Furthermore, HICl hypermethylation was found in almost all recurrent acute lymphocytic 
leukemia and blast crisis of chronic myelogenous leukemia proposing a $\mathrm{HICl}$ hypermethylation to be a late event in haematopoietic malignancies $(18,32)$.

Therefore, overall data concerning methylation and expression of $\mathrm{HICl}$ varies depending on organic system, tissue origin and cancer subtype suggesting a differentiated function of $\mathrm{HICl}$. Of note, we were able to show an association of $\mathrm{HICl}$ hypermethylation and shortened recurrence-free survival which severely underlines the importance of $\mathrm{HICl}$ CGI-hypermethylation in RCC.

In addition the association of hypermethylation and shortened recurrence-free survival in RCC has only been shown for only a few analyzed genes so far. For $D A P K-1$ as well as for $S C U B E 3$ an association with an increased risk of recurrence has been shown $(10,33)$. Van Vlodrop et al were also able to show significantly worse survival to be associated with methylation of one region within the GREM-1 CGI in univariate analysis and decreased overall survival in correlation with hypermethylation of another GREM-1 CGI subregion in multi- and univariate analysis (34). By creating a combined methylation score for the Wnt-Antagonists $s F R P-1, s F R P-2, s F R P-4, s F R P-5$, Wif- 1 and $D k k$-3 Urakami et al instead of were able to show statistical association with a shortened overall survival found $S F R P 1$, $B N C 1$ and COL14Al to be related with poor prognosis $(9,35)$. From a clinical point of view at yet only few CGIs show statistical association with clinical parameters. Thus, the independent prognostic information provided by $\mathrm{HICl}$ CGI methylation in RCC may be of clinical value. In addition, we found evidence that hypomethylation of $\mathrm{HICl}$ could be associated with the presence of lymph node metastases, although low odds ratios were detected and the effect could not be seen in the subgroup of clear cell RCCs. This uncertain result would also partially contradict a study recently published by Fleuriel et al (18). Fleuriel et al proposing an association of $\mathrm{HICl}$ hypermethylation with aggressive tumor behavior. However our finding that quantitatively measured $\mathrm{HICl}$ CGI methylation is an independent predictor of recurrence-free survival agrees well with the results of Fleuriel et al describing a relationship with poor prognosis of patients $(17,18,23,29,36-38)$.

The most studied functional interaction of $\mathrm{HICl}$ is the complex HIC1-p53-SIRT regulatory loop. Within this pathway inactivation of $\mathrm{HICl}$ is followed by an upregulation of SIRT that is able to deactivate $\mathrm{p53}$, which can in turn upregulate HICl expression $(18,20)$. Cells with inactivated $\mathrm{p} 53$ will bypass apoptosis and survive DNA damage insted of leaving insert providing a functional explanation how epigenetic silencing of $\mathrm{HICl}$ increases risk for cancer development.

Jenal et al showed that $\mathrm{HICl}$ can be induced by cell cycles and apoptosis regulator E2F1, one out of eight genes of the E2F family (39). However, in a regulatory loop $\mathrm{HICl}$ also directly regulates E2F-responsive genes and thereby represses cell growth. The complex interactions of p53 and $\mathrm{E} 2 \mathrm{~F}$ in vital cellular processes, their cooperation in restriction of tumor development and pro-apoptotic function as well as their well known deregulation in human cancers suggest $\mathrm{HICl}$, being linked to either one, to play an important role in cancer development (40). Noteworthy, a study concerning tumor cell response in breast cancer was also able to show that $\mathrm{HICl}$ mediates growth suppression by estrogen antagonists in breast cancer cells. Demonstrating that $\mathrm{HICl}$ expression correlates with growth repression in sensitive tumor cells while in antagonist-resistant tumor cells induction of $\mathrm{HICl}$ is lost, this study clearly indicates the complexity of $\mathrm{HICl}$ (41). Both the potential clinical relevance as well as interactions of $\mathrm{HICl}$ epigenetic alterations with cellular regulation are not fully understood at yet therefore underlining the need to take a closer look at $\mathrm{HICl}$ function in renal cancer model systems.

In conclusion, $\mathrm{HICl}$ hypermethylation is associated with reduced recurrence-free survival in RCC. Therefore, $\mathrm{HICl}$ could be seen as a possible marker to improve individualized therapy and risk stratification. Future studies will have to focus on functional analysis to further elucidate the role of $\mathrm{HICl}$ in RCC.

\section{References}

1. Nelson EC, Evans CP and Lara P: Renal cell carcinoma: Current status and emerging therapies. Cancer Treat Rev 33: 299-313, 2007.

2. Drucker BJ: Renal cell carcinoma: Current status and future prospects. Cancer Treat Rev 31: 536-545, 2005.

3. Whang YE and Godley PA: Renal cell carcinoma. Curr Opin Oncol 15: 213-216, 2003.

4. Cheng L, Zhang S, MacLennan GT, Lopez-Beltran A and Montironi R: Molecular and cytogenetic insights into the pathogenesis, classification, differential diagnosis, and prognosis of renal epithelial neoplasms. Hum Pathol 40: 10-29, 2009.

5. Baldewijns MM, van Vlodrop IJ, Schouten LJ, Soetekouw PM, de Bruine AP and van Engeland M: Genetics and epigenetics of renal cell cancer. Biochim Biophys Acta 1785: 133-155, 2008.

6. McRonald FE, Morris MR, Gentle D, et al: $\mathrm{CpG}$ methylation profiling in VHL related and VHL unrelated renal cell carcinoma. Mol Cancer 8: 31, 2009.

7. Dalgliesh GL, Furge K, Greenman C, et al: Systematic sequencing of renal carcinoma reveals inactivation of histone modifying genes. Nature 2: 360-363, 2010.

8. Varela I, Tarpey P, Raine K, et al: Exome sequencing identifies frequent mutation of the SWI/SNF complex gene PBRM1 in renal carcinoma. Nature 27: 539-542, 2011.

9. Morris MR, Ricketts C, Gentle D, et al: Identification of candidate tumour suppressor genes frequently methylated in renal cell carcinoma. Oncogene 8: 2104-2117, 2010.

10. Morris MR, Ricketts CJ, Gentle D, et al: Genome-wide methylation analysis identifies epigenetically inactivated candidate tumour suppressor genes in renal cell carcinoma. Oncogene 24: 1390-1401, 2011.

11. Cairns P: Detection of promoter hypermethylation of tumor suppressor genes in urine from kidney cancer patients. Ann NY Acad Sci 1022: 40-43, 2004.

12. Hoque MO, Begum S, Topaloglu O, et al: Quantitative detection of promoter hypermethylation of multiple genes in the tumor, urine, and serum DNA of patients with renal cancer. Cancer Res 1: 5511-5517, 2004.

13. Serth J, Tezval H, Peters I, et al: Methylation of the RASSF1A tumor suppressor gene promoter. risk factor for carcinogenesis of urological tumors. Urologe A 47: 1117-1121, 2008 (In German).

14. Peters I, Rehmet K, Wilke N, et al: RASSF1A promoter methylation and expression analysis in normal and neoplastic kidney indicates a role in early tumorigenesis. Mol Cancer 16: 49, 2007.

15. Awakura Y, Nakamura E, Ito N, Kamoto T and Ogawa O: Methylation-associated silencing of SFRP1 in renal cell carcinoma. Oncol Rep 20: 1257-1263, 2008.

16. Dahl E, Wiesmann F, Woenckhaus M, et al: Frequent loss of SFRP1 expression in multiple human solid tumours: Association with aberrant promoter methylation in renal cell carcinoma. Oncogene 16: 5680-5691, 2007.

17. Wales MM, Biel MA, el Deiry W, et al: p53 activates expression of HIC-1, a new candidate tumour suppressor gene on $17 \mathrm{p} 13.3$. Nat Med 1: 570-577, 1995.

18. Fleuriel C, Touka M, Boulay G, Guerardel C, Rood BR and Leprince D: HIC1 (hypermethylated in cancer 1) epigenetic silencing in tumors. Int J Biochem Cell Biol 41: 26-33, 2009. 
19. Pinte S, Stankovic-Valentin N, Deltour S, Rood BR, Guerardel C and Leprince D: The tumor suppressor gene HIC1 (hypermethylated in cancer 1) is a sequence-specific transcriptional repressor: Definition of its consensus binding sequence and analysis of its DNA binding and repressive properties. J Biol Chem 10: 38313-38324, 2004.

20. Chen WY, Wang DH, Yen RC, Luo J, Gu W and Baylin SB: Tumor suppressor HIC1 directly regulates SIRT1 to modulate p53-dependent DNA-damage responses. Cell 4: 437-448, 2005.

21. Van Rechem C, Boulay G and Leprince D: HIC1 interacts with a specific subunit of SWI/SNF complexes, ARID1A/BAF250A. Biochem Biophys Res Commun 7: 586-590, 2009.

22. Zhang B, Chambers KJ, Leprince D, Faller DV and Wang S: Requirement for chromatin-remodeling complex in novel tumor suppressor HIC1-mediated transcriptional repression and growth control. Oncogene 5: 651-661, 2009.

23. Makos M, Nelkin BD, Reiter RE, et al: Regional DNA hypermethylation at D17S5 precedes $17 p$ structural changes in the progression of renal tumors. Cancer Res 15: 2719-2722, 1993.

24. Eilers T, Machtens S, Tezval H, et al: Prospective diagnostic efficiency of biopsy washing DNA GSTP1 island hypermethylation for detection of adenocarcinoma of the prostate. Prostate 15: 757-763, 2007.

25. Colella S, Shen L, Baggerly KA, Issa JP and Krahe R: Sensitive and quantitative universal Pyrosequencing methylation analysis of CpG sites. Biotechniques 35: 146-150, 2003.

26. van Vlodrop IJ, Niessen HE, Derks S, Baldewijns $M$, Van Criekinge W, Herman JG and van Engeland M: Analysis of promoter $\mathrm{CpG}$ island hypermethylation in cancer: Location, location, location! Clin Cancer Res 7: 4225-4231, 2011.

27. Potapova A, Albat C, Hasemeier B, et al: Systematic crossvalidation of 454 sequencing and pyrosequencing for the exact quantification of DNA methylation patterns with single $\mathrm{CpG}$ resolution. BMC Biotechnol 14: 6, 2011.

28. Makos M, Nelkin BD, Chazin VR, Cavenee WK, Brodeur GM and Baylin SB: DNA hypermethylation is associated with $17 \mathrm{p}$ allelic loss in neural tumors. Cancer Res 15: 2715-2718, 1993.

29. Rood BR, Zhang H, Weitman DM and Cogen PH: Hypermethylation of HIC-1 and $17 \mathrm{p}$ allelic loss in medulloblastoma. Cancer Res 62: 3794-3797, 2002.
30. Fujii H, Biel MA, Zhou W, Weitzman SA, Baylin SB and Gabrielson E: Methylation of the HIC-1 candidate tumor suppressor gene in human breast cancer. Oncogene 23: 2159-2164, 2008.

31. Morton RA,Jr, Watkins JJ, Bova GS, Wales MM, Baylin SB and Isaacs WB: Hypermethylation of chromosome 17P locus D17S5 in human prostate tissue. J Urol 156: 512-516, 1996.

32. Issa JP, Zehnbauer BA, Kaufmann SH, Biel MA and Baylin SB: HIC1 hypermethylation is a late event in hematopoietic neoplasms. Cancer Res 1: 1678-1681, 1997.

33. Christoph F, Weikert S, Kempkensteffen C, et al: Promoter hypermethylation profile of kidney cancer with new proapoptotic p53 target genes and clinical implications. Clin Cancer Res 12: 5040-5046, 2006.

34. van Vlodrop IJ, Baldewijns MM, Smits KM, et al: Prognostic significance of Gremlin1 (GREM1) promoter $\mathrm{CpG}$ island hypermethylation in clear cell renal cell carcinoma. Am J Pathol 176: 575-584, 2010.

35. Urakami S, Shiina $\mathrm{H}$, Enokida $\mathrm{H}$, et al: Wnt antagonist family genes as biomarkers for diagnosis, staging, and prognosis of renal cell carcinoma using tumor and serum DNA. Clin Cancer Res 12: 6989-6997, 2006.

36. Hayashi M, Tokuchi Y, Hashimoto T, et al: Reduced HIC-1 gene expression in non-small cell lung cancer and its clinical significance. Anticancer Res 21: 535-540, 2001.

37. Kanai Y, Hui AM, Sun L, Ushijima S, Sakamoto M, Tsuda H and Hirohashi S: DNA hypermethylation at the D17S5 locus and reduced HIC-1 mRNA expression are associated with hepatocarcinogenesis. Hepatology 29: 703-709, 1999.

38. Nicoll G, Crichton DN, McDowell HE, Kernohan N, Hupp TR and Thompson AM: Expression of the hypermethylated in cancer gene (HIC-1) is associated with good outcome in human breast cancer. Br J Cancer 14: 1878-1882, 2001.

39. Jenal M, Trinh E, Britschgi C, et al: The tumor suppressor gene hypermethylated in cancer 1 is transcriptionally regulated by E2F1. Mol Cancer Res 7: 916-922, 2009.

40. Polager S and Ginsberg D: p53 and E2f: Partners in life and death. Nat Rev Cancer 9: 738-748, 2009.

41. Zhang B, Faller DV and Wang S: HIC1 regulates tumor cell responses to endocrine therapies. Mol Endocrinol 23: 2075-2085, 2009. 